\title{
Phenomenology and hermeneutics as a basis for sensitivity within health care
}

\author{
Janne Brammer Damsgaard RN, MScN, PhD, Co-founder of Centre for Hope, \\ Dreams and Wellbeing \& external lecturer ${ }^{\circ}$
}

Research Unit of Nursing and Health Care, Department of Public Health, Aarhus University, Aarhus, Denmark

\section{Correspondence}

Janne Brammer Damsgaard, Research Unit of Nursing and Health care, Department of Public Health, Aarhus University, Denmark.

Email: jannedamsgaard@webspeed.dk

\begin{abstract}
An educated healthcare professional or student is sensitive and able to make good judgements, understanding existential challenging issues. It is argued that the ideas within phenomenology and hermeneutics can function as a basis for comprehension. This article focuses on how choice of perspective and knowledge is of importance to what we do in practice. However, education does not consist of mere accumulation of knowledge and ways of explanation. We do not become competent practitioners by being able to reproduce philosophical ideas. These are merely perspectives by means of which we can seek to go beyond what we take for granted, or what we assume to know, thus enabling us to take a new direction understanding problems and issues that until now may have been hidden to us. In other words, understanding is of an existential character, whereas an observing healthcare professional must be aware and open to the mental aspects of life. It is therefore important to attune ourselves to being sensitive to and aware of experiences from our lifeworld, understanding what they imply. It is argued that literature provides insight into human nature through the written depiction of real or imagined experiences. To develop such narrative imagination, it is suggested that literature should be part of the curriculum of various educations. This is relevant to healthcare professionals who thereby can get an important insight into human nature and begin to develop the self-awareness and sensitivity to others that is so central to care.
\end{abstract}

\section{KEYWORDS}

care, existential aspects, knowledge, literature, phenomenology and hermeneutics, sensitivity

\section{1 | INTRODUCTORY REFLECTIONS}

When we as healthcare professionals relate to and cooperate with people, it is all important to reflect upon the ulterior reasons that may constitute other people's motives for acting, taking their knowledge and general understanding, as well as our own, into consideration. The present article focuses on phenomenology and hermeneutics as a basis for comprehension within nursing, at the same time as it elucidates how philosophy and theory of science traditionally have defined knowledge and perception.
The two major philosophical schools are examined and displayed with a view to answering the question: What are the elements of educational potential, perspective and basis of perception within phenomenology and hermeneutics.

Using different philosophical viewpoints, the article focuses on how knowledge and choice of perspective are of importance to what we do in practice. However, it is important to say that phenomenology and hermeneutics as established traditions within philosophy and scientific theory comprise philosophical thinking and theory of interpretation-not methods which can be immediately turned into practice. 
This article illustrates how awareness and application of a phenomenological and hermeneutic perspective can help us to open our eyes to otherwise easily missed, 'invisible' existential aspects of life.

\section{2 | HEALTHCARE PROFESSIONALS GAINING INSIGHT INTO HUMAN LIFE}

The phenomenological, hermeneutic and phenomenological-hermeneutic perspective is not only an epistemology, but it also comprises a way of existing as a human being, an ontology. A phenomenological and hermeneutic perspective is therefore conductive to sensitivity in relation to visualize and understand aspects of human existence. The openness, attention and understanding concerning interhuman relations, which are embedded here, can be helpful within the practice of nurses and other healthcare professionals to throw light on existential aspects of life.

\section{3 | PHENOMENOLOGY-A HUMAN PERSPECTIVE}

The founding father of phenomenology is considered to be the German philosopher Edmund Husserl (Zahavi, 2018). Husserl focuses on consciousness, in that he looks at the human being as a complex entity, not only in a physical sense, but also by being in a world of consciousness. This world of consciousness is not seen as separated from the body, seeing that it constitutes a conscious bodily based being. The human world of consciousness is inseparably linked with the human physicality, out of which the particularly human element grows. However, if I take a closer look, which means that I turn to my own consciousness and now reflect and concentrate on what appears to me here, I will realize that I am always oriented towards a certain object. I do not merely see something or other, but something definite or specific. There is always something that is the focus of my attention, namely the intentional object (ibid.). I always see an object-a patient or a problem which I have to solve-on the background of a horizon of other objects, which are not in focus. Husserl describes this as orientedness (Husserl, 2009).

During the very act of perception, when I catch sight of something, I am oriented towards the object, for instance the paper; I perceive it as being here-andnow. This perceptive understanding singles it out on a background. Around the paper there are books, pencils, an ink horn etc., which in a way also are being 'observed', perceived right there within my 'field of vision'. However, while I am oriented towards the paper, the other objects will lack any sort of attention, even a secondary one. They appear, but they are nevertheless not singled out, not seen in their own right

(ibid.).
According to Husserl (and the phenomenological perception), the human being thus has an awareness-based perspective on the world. This particularly human element is 'elusive' when in terms of the natural sciences you view and explain the human being as a natural creature. According to phenomenology, the problem is not the methods of the natural sciences, but the circumstance that you solely view the human being from a natural scientific angle, like a body among so many others. As the philosopher Torben Andreasen says, the consciousness is only visible from a different perspective. You have to catch hold of the particular consciousness-related aspects by means of a mental conceptual register, which is capable of focusing on just that, for instance to have pain, to experience, to consider, to feel, to grieve, etc. (Andreasen, 2006).

It is possible to talk about the human being as a bodily entitybut then it can mean two things. It can mean body in the same sense as we talk about mobile phones, cars or flowers. Seen from that perspective, I follow the rules of physics. If, for example, I step out from a balcony, I follow the rules of physical laws concerning bodily motion. Here, I am seen as a purely physical body, where you can calculate the speed at which I fall, when I shall hit the ground, etc. But here is where the second meaning of a body comes in. Is it really possible to use the physical perspective on me, the way you can use it on a mobile phone that falls over the edge of a balcony? As it is, I am not merely a physical body, which can be described in terms of the language of physics, but I am also a human being, that is a particular bodily entity equipped with a consciousness. In this sense, it is not correct to say: 'It was just a body that fell over the edge there, did you see that?' The description is not adequate. I am not just a body, but a fateful human being, who faces the end of my life in a tragical way.

In the same way, we can look at the matter with our health professional spectacles on. If, for example, the nurse says to the doctor: 'The appendicitis case you will find in room 14', similarly if the nurse describes the patients as 'back patients or borderline patients'. Here, the human being suffering from appendicitis, back pain or psychological challenges has been reduced to a thing and to a number in the row of patients-the human perspective is missing!

\subsection{The lifeworld and the mental aspects of life}

If you want to gain knowledge about the particular sides of what it means to be a human being-a patient, you must go into the particularly human aspect, namely the lifeworld, the very place where people are and where they live their lives. How to grasp this perspective and the lifeworld is not something that you can find the answer to from phenomenology. Here, it is just said that you ought to view the human being from a certain perspective. If you do not apply this particular perspective, there will be sides of reality that you do not manage to include (ibid.). Seen from a humanist perspective, for example, an observing student or nurse is required to be prepared to include the mental aspects of life. If we are not able to see that a person becomes afraid, if we cannot feel that a person is in pain, or if we are unable to hear that a person is nervous-well, then we lack a 
fundamental feeling for these aspects of life-and therefore we have to be trained. Through education and training, we must develop our potential in terms of reflection and sound judgement.

\section{4 | HERMENEUTICS-TO PREPARE ONESELF TO BE OPEN AND PERCEPTIVE}

Phenomenology focuses on our consciousness, whereas the project of the German philosopher Hans-Georg Gadamer is to describe, what happens when we perceive. The purpose of perception is not only to understand the other person or the other thing/phenomenon, perception is also always perception of self (Gadamer, 2007). These aspects are essential to the way in which we act and make decisions as nurses and other healthcare professionals, and consequently, it is equally important to be aware of the premises determining why we act as we do.

\section{1 | To prepare oneself to be open and perceptive}

Understanding is not equivalent to getting to know about somebody else's horizon in terms of reliving. We cannot do such a thing. Nor is understanding a method to become acquainted with the other person's horizon. Such a method does not exist (Jensen, 1990). According to Gadamer, understanding is something that comes to us or happens to us, if we are prepared for it (Gadamer, 2007). This is among other things what is meant when we say that understanding is always also an act of understanding ourselves. Understanding depends on ourselves and consequently also what we as human beings have brought with us, formed through upbringing, formative education and culture, and also including the pre-judices and expectations that we have taken over. To put it briefly, healthcare professional's understanding is obtained by being open and receptive to what the patient tries to communicate-and, a thing which is of great importance (and difficult), by refraining from the temptation to understand what the patient says, that is to try to recreate a situation, where the message becomes meaningful, and to explain (away) the patient's statement by referring to what you believe.

\subsection{The other person/the patient as a peer}

Understanding according to Gadamer is equal to perceiving the other person as a person who is recognized as one's own peer (ibid.: 358-359). Understanding requires that you see the patient as an equal person who, like yourself, is capable of speaking-and actually also does speak-words that are true, sensible and meaningful, and who also, like yourself, is able to add to an understanding through the conversation that is held. If the nurse does not meet the patient with this moral attitude, understanding will not occur at all. If for instance you look upon the patient as an ignorant person, who needs to be given instructions about what illness basically is all about, you are already on your way to explain (away) the patient's acts and stories on the basis that does not take the other person's experiences with her illness seriously.

Understanding is a way of being-which means that you use your own overall, aggregate experience to be open, reasoned, concrete and to show a presence of mind. Seen from a hermeneutic angle, this means that certain aspects of the world can only be appreciated through experiences and that you may change as a person by being ready to risk your pre-judgement concerning the other person (or maybe give it up completely). This entails that as a nurse you are for example all the time evaluating or assessing whether tables, models, theories, experience, etc., give you a better understanding of the patient in question. Seen through hermeneutic spectacles, the understanding of a patient is not a question about making this person fit into your own pre-judgement, but instead to continuously reflect upon whether your own understanding (e.g. based on tables, charts and theories) is relevant.

\section{I FORMATION THROUGH EDUCATION- CONSCIOUSNESS AND PERCEPTION OF OTHER PEOPLE'S LIVES}

The Greek philosopher Heraklit described how the philosopher Thales gathered knowledge about everything and became an able human being. All the same he only understood little, Heraklit thought. Heraklit even went so far as to accuse him of being 'a fool with a know-all attitude' (Hellesnes, 1999). Thales was in possession of a fractured, wide range of elements of knowledge, but he lacked an overall view and understanding of how he could unite the many fragments and organize them into meaningful entities. He had not opened himself to wisdom and therefore was not able to judge how to apply his vast amount of knowledge.

Outlook and a broad view of things primarily spring from formal education, and not from a plethora of formal education (ibid.). Education means our ability to reflect on life and the surrounding everyday life, which is always our starting point. By way of illustration, an educated student or healthcare professional is able to make good use of judgement, ingenuity and kindness by opening the eyes to people and their range of problems. You may say that this is essentially what phenomenology and hermeneutics are all about, namely to raise one's consciousness and perception of other people's lives.

It is evident that nurses need to understand how for example the body works, how medications affect the body-skills that are not philosophical. However, the point is that being a competent nurse or healthcare professional does not consist of accumulation of knowledge and ways of explanation such as diagrams, structures and theories. Following Heraklit's line of arguing, we do not become competent nurses by being able to reproduce Husserl's or Gadamer's theoretical ideas. The philosophies are merely a perspective and a means of support, by means of which we can seek to go beyond what we take for granted, or what we assume to know, thus enabling us to take a new direction and enable ourselves to understand 
problems and issues that until now may have been hidden to us. That is what education seen from a phenomenological and hermeneutic perspective strives to open up for.

\section{6 | COGNITION OF AN EXISTENTIAL NATURE}

Phenomenology and hermeneutics are occupied with raising awareness of and creating understanding of aspects of human existence. However, it is erroneous if we believe that the philosophies in themselves can prescribe anything about practice. According to the American philosopher Martha Nussbaum, it can be a downright hindrance to seeing anything at all, and the result may be that we do not meet the world and our fellow human beings with the necessary openness and attention (Nussbaum, 1997).

\section{7 | EDUCATION WHICH IS CAPABLE OF PREVAILING IN OUR SOULS}

The Greek philosopher Plato made a poignant statement when expressing that the cognition or knowledge that we obtain through a formulation or opinion or a mere application of an idea from somebody else is an impotent cognition. This form of perception is not capable of prevailing in our souls and consequently has no relation to any form of genuine educational or informational value (Lindskog, 1984). What Plato has in mind here is the skilfulness of the Sophists who through their eloquence could beguile their listeners so that they ended up with taking a specific, intended view of things. Such a type of cognizance is superficial in the sense that it merely consists of words and phrases that can be learned scholastically, but which does not affect our souls.

The type of cognition that the philosophers Aristotle and Plato saw as the true cognition was of quite a different order than the one peddled by the Sophists. To Plato, true cognition did not consist of words, phrases or theories and therefore could not be obtained through the written word. It was something that was latent in our souls and waited for being set free. True cognition was in other words of an existential character. Within this perspective, cognition cannot be taught or transferred from one person to the other. It can only be obtained in an indirect way, when somebody else furthers it, which is the reason why it does not make any sense to give lectures to one's students in the Sophist way (Birkelund, 2014) or explain (away) how nurses and healthcare professionals perceive patients pain or sorrow-this must be obtained and understood through experiences from our lifeworld.

\section{8 | EXPERIENCES FROM THE LIFEWORLD}

The chain of reasoning that true cognition is of an existential nature may be said to be the foundation behind phenomenology. To illustrate this, we would not be capable of fathoming the depths of such concepts as trust, care and other types of recognition from actual life without having had concrete experiences pertaining to these phenomena.

The eidetic meaning of these concepts and their implications can only be recognized on the basis of our experience of the world, that is from the world that the founder of modern phenomenology, Edmund Husserl, designated as the lifeworld. Which is to say the world that we live in and which comes before all theoretical definitions and explanations of what trust, care, recognition, anxiety, stress, etc., are and what they mean (ibid.). Along the same lines, the philosopher Maurice Merleau-Ponty has written that concepts are only meaningful if we have prerequisite qualifications based on experience to understand what they imply.

All that I know about the world, even acquired through science, I know on the basis of my own point of view or from an experience of the world, without which the symbols of science would be meaningless. The whole universe of science is built upon the world as directly experienced, and if we want to subject science itself to rigorous scrutiny and arrive at a precise assessment of its meaning and scope, we must begin by reawakening the basic experience of the world of which science is a second-order expression (MerleauPonty, 2002).

It is therefore important attuning ourselves to our experiences from our lifeworld trying to understand what they imply. This is important knowledge to healthcare professionals.

\section{9 | ATTUNING OURSELVES}

As described by Aristotle, the idea that you first learn through theory and then apply it in practice is not a valid idea, because knowledge that is remembered must have connection to the lived life. On the other hand, it is meaningful to put focus on the traditions of philosophy and scientific theory comprising phenomenology and hermeneutics, since the philosophical schools that are linked with this tradition in different ways seek to make visible and understand the human existence. Realizing that we cannot make use of phenomenology and hermeneutics in a direct way, we must ask ourselves what to do? Once again, we can turn to the Greek philosophers and the concept of academia, which was a place where theoria was paramount. Theoria was a type of activity, and academia was a dialog-based Oasis. Here, the participants not only tried to develop abstract thinking, but also wisdom, which was the same as learning as much about the world and oneself as possible.

Therefore, Theoria is to be understood as a process of formation with thoughtfulness and reflection as the main concerns. This type of activity can be sought after and emulated by us as students and nurses through being open and attentive individuals, who enter into 
dialogue with our fellow human beings, for example patients, relatives and colleagues. By entering the community which we are surrounded by at home, during our education, on the job, etc., we must strive to get to know ourselves. That is a good starting point, if we want to attune ourselves as humans and try to understand the world from a phenomenological and hermeneutic perspective.

Looking at this in a context of nursing, it means that we must provide time and room for defining as well as reflecting upon the phenomena and issues that are part of practical nursing in the real world. This is where phenomenology can be of help to us because of its special approach to describing people's lives, in combination with the art of interpretation taken from the field of hermeneutics. The openness, attention and theory of understanding that are central efforts in this context can help us shed an existential light over a concrete case or issue, which is connected with practice. But philosophy cannot say anything concrete about a specific situation.

On the other hand, theories can help us interpret and understand the experiences of life in certain areas. For instance, the fact that grief is involved when you lose a family member is not a thing that philosophy can help us understand; here, a particular effort is required of a healthcare professional or scientific nature.

But how are these skills developed? How do we form our ability to understand? If we look at what we have said above, this capability is not acquired through drilling. In the novel Stolen Spring, the author Hans Scherfig presents his reflections of the subject (Scherfig, 1940).

\section{Excerpt from the novel Stolen Spring}

And it is not acceptable that you forget anything: You don't keep all the food that you eat inside you. But the spiritual food that you imbibe in school has to be stored. There is still a great number of exams to be passed, and you must remember and remember. You must economize with your brain, and not read anything that is not required for the set exams curriculum.

There are many books that you would like to read, but that is not acceptable. It might drive out the matter that you must remember. There is no room for private interests and for private thirst of knowledge. This is a well-known fact for Axel Nielsen. He is still able to keep his position as number one in class, but he never dares read a book which is not a school book. He never ventures to read a newspaper. To take good care of his proper formation he has to be without any knowledge of the relations, problems and thoughts of other human beings:

Old-fashioned, - says the lady at Landemaerket. Oh, my Lord! Is there no end to it? Your heads must swell like balloons. How on earth can there be room in there for any ordinary sensible tings?

Scherfig is on a line with Aristotle when he points out that the educational process of reflection and afterthought demands more than merely to be able to reproduce your examination curriculum. Also with inspiration from Aristotle, the American philosopher Martha Nussbaum is dealing with how to tackle this challenge. Nussbaum has suggested that literature should be part of the curriculum of various educations. She thinks that dealing with literature is a way to develop 'narrative imagination', that is sensitivity, capacity for showing empathy and sense of occasion within interhuman relations (Nussbaum, 1997). The same idea has been taken up by nursing theorist Regner Birkelund, a Danish researcher within nursing, who writes that literature is about phenomena of life.

Imaginative literature deals with phenomena of life, i.e. phenomena that belong to the realm of human existence for good or bad, which therefore holds information of relevance to understanding people's lives from a phenomenological perspective. Hence of general relevance, not least for professional people who work within care (Birkelund, 2011).

Literature provides insight into human nature through the written depiction of real or imagined experiences. The solitary nature of reading tends to foster introspection and the development of self-awareness. Through literature, nurses (healthcare professionals) therefore can begin to develop the sensitivity to others that is so central to nursing and care.

\section{0 | FINAL REMARKS}

To illustrate how awareness and application of a phenomenological and hermeneutic perspective can help healthcare professionals to open their eyes to otherwise easily missed, 'invisible'/subtle existential aspects of life, this article has presented arguments for the necessity to be in possession of a formative education, which consists of experience with reflecting over the lifeworld, and how to understand it. This is not only done by reproducing theoretical ideas, which may actually prevent us from seeing important existential realizations, which are waiting to be disclosed. What is required is developing an awareness to our lifeworld, which leads to the formative education of competent and wise human beings who are in possession of sensitivity and understanding. A phenomenological and hermeneutic perspective is conductive to sensitivity in relation to visualize and understand aspects of human existence. The openness, attention and understanding concerning interhuman relations, which are embedded here, may be helpful to throw light on the existential aspects of life, and this can be obtained by reading different kinds of literature. How to get hold of this potential and train the skills as a basis for our practical actions, and how to open 
up to human existence as such, will be described in another article arguing for integrating the arts into nursing.

\section{CONFLICT OF INTEREST}

None.

\section{ORCID}

Janne Brammer Damsgaard (DD https://orcid.

org/0000-0003-1238-2344

\section{REFERENCES}

Andreasen, T. E. (2006). Fænomenologi og videnskab. Del 1. Tidsskrift for Sygeplejeforskning, 22(2), 28-36.

Birkelund, R. (2011). Det æstetiske indtryk - en menneskelig livsfornødenhed. Ved livets afslutning - om palliativ omsorg, pleje og behandling. : Aarhus Universitetsforlag.

Birkelund, R. (2014).Forskellige vidensformer - muligheder og begrnsninger. In æK. Frederiksen, \& B. Glinsvad (Eds.), Fag. Grundbog i sygepleje. Munksgaard: pp. 241-257.

Gadamer, H.-G. (2007). Sandhed og metode: Grundtræk af en filosofisk hermeneutik. : Systime Academic.
Hellesnes, J. (1999). En uddannet mand og et dannet menneske. Oplæg til et udvidet dannelsesbegreb. Pædagogisk filosofi. E. L. Dale. Forlaget Klim.

Husserl, E. (2009). Ideen zu einer reinen Phänomenologie und phänomenologischen Philosophie, Germany: Felix Meiner Verlag.

Jensen, T. K. (1990). Sygepleje som etisk know-how - hermeneutik og livsverden, menneskesyn og metode. Grundlagsproblemer i sygeplejen. Etik, videnskabsteori \& samfund. T. K. Jensen, L. U. Jensen and W. C. Kim. : Forlaget Philosophia.

Lindskog, C. (1984). Faidros. Platons samlade skriftar. Bokförlaget Doxa $A B$.

Merleau-Ponty, M. (2002). Phenomenology of perception 2.(1-488). London: Routledge.

Nussbaum, M. (1997). Cultivating humanity. A classical defense of reform in liberal education, Cambridge, Massachusetts, London, England: Harvard University Press.

Scherfig, H. (1940). Det forsømte forår. Gyldendal.

Zahavi, D. (2018). Fænomenologi. En introduktion. Samfundslitteratur.

How to cite this article: Damsgaard JB. Phenomenology and hermeneutics as a basis for sensitivity within health care. Nurs Philos. 2020;00:e12338. https://doi.org/10.1111/ nup.12338 